\title{
PENJADWALAN SHIFT KERJA MENGGUNAKAN METODE ALGORITMA TIBREWALA, PHILIPPE, DAN BROWNE DI BAGIAN ASSY INSPECTION PT. HI-LEX PARTS INDONESIA
}

\author{
Agus Taufik \\ Dosen Fakultas Teknik Prodi Teknik Industri Universitas Pamulang \\ Dosen01301@unpam.ac.id
}

\begin{abstract}
ABSTRAK
Penelitian ini merupakan penelitian deskriptif kualitatif yang dilakukan pada PT. Hi-Lex Parts Indonesia di bagian Assy Inspection yang meliputi proses penjadwalan sistem shift kerja yang menggunakan Metode Algoritma Tibrewala, Philippe, dan Browne. Metode ini pertama kali diperkenalkan oleh Tibrewala, Philippe, dan Browne pada tahun 1972. Penelitian ini bertujuan untuk memenuhi permintaan terhadap pekerja dengan meminimumkan jumlah pekerja yang harus disiapkan. Dari hasil penelitian dan analisis ini dapat diketahui bahwa Metode Algoritma Tibrewala, Philippe, dan Browne memerlukan tambahan tenaga kerja sebanyak 27 orang menggunakan sistem 5 hari kerja dengan 40 jam kerja per minggu tanpa ada kerja lembur dan mengurangi pengeluaran biaya upah lembur sebesar $11 \%$ (sebelas persen) dalam 1 tahun
\end{abstract}

Kata Kunci: Shift Kerja, Biaya, Metode Algoritma Tibrewala, Philippe.

\section{PENDAHULUAN}

Seiring dengan kebutuhan masyarakat yang terus meningkat disertai dengan perkembangan teknologi yang semakin pesat, maka tuntutan akan produkpun semakin beragam dan terus menerus berkembang sesuai dengan perubahan zaman. Di dalam kehidupannya manusia tidak lepas dari berbagai macam kebutuhan, mulai dari kebutuhan dasar sampai pada tingkat kebutuhan yang lebih tinggi. Hal ini menuntut para produsen untuk meningkatkan kualitas dan produksinya. Dimana dalam melaksanakan suatu aktivitas produksi pasti membutuhkan suatu perencanaan yang matang untuk menghindari atau mengurangi tingkat kerugian pada perusahaan tersebut.

Pada setiap perusahaan pasti menginginkan pekerjaan yang di laksanakan di perusahaannya dapat berjalan secara efektif dan efisien, demi tercapainya tujuan utama perusahaan tersebut. Oleh karena itu, pemahaman mengenai konsep penjadwalan sangat penting, sehinggga para pelaksana mengetahui kapan waktu harus memulai suatu pekerjaan dan kapan waktu harus mengakhirinya (Liestyowati Ir, ME, 2005). Sedangkan tujuan dari penjadwalan ini adalah untuk mengefisienkan produktivitas dari tiap-tiap elemen aktivitas pada suatu perusahaan. Perencanaan yang matang perlu kita lakukan sebelum produksi dilakukan, hal ini bertujuan untuk memaksimalkan sumber daya yang kita miliki untuk menekan biaya produksi hingga seminimal mungkin. Tanpa suatu perencanaan yang matang, perusahaan tidak akan mampu menyerap fluktuasi demand yang terjadi sehingga cenderung terjadi penumpukan di gudang atau lost sales yang merugikan perusahaan (Utus Syafaat, 2004). Oleh karena itu perlu diadakannya penjadwalan yang mengatur semua aspek aktifitas pada suatu perusahaan.

\section{LANDASAN TEORI}

\section{A. Shift Kerja}

Produktivitas kerja karyawan dapat diusahakan dengan melakukan pembagian kerja sesuai dengan waktu kerja atau bisa diistilahkan dengan shift work. Jewel dan Siegal mengartikan shift kerja sebagai strategi penjadwalan jam kerja sedemikian rupa sehingga kelompok karyawan tetap yang berbeda melakukan tugas pekerjaan yang sama dalam jangka waktu yang berbeda selama 24 jam.

\section{B.Pengauh Shift Kerja Terhadap Kesehatan Fisik \\ Sudah dipercaya bahwa sebagian besar dari pekerja yang bekerja pada Shift malam memiliki resiko yang lebih tinggi untuk mengalami}


kecelakaan kerja dibandingkan dengan mereka yang bekerja pada shift normal (shift pagi). Josling (1998) dalam artikelnya yang berjudul Shift Work and III-Health mempertegas anggapan tersebut dengan menyebutkan hasil penelitian yang dilakukan oleh The Circadian Learning Centre di Amerika Serikat yang menyatakan bahwa para pekerja Shift, terutama yang bekerja dimalam hari, dapat terkena beberapa permasalahan kesehatan.

Permasalahan kesehatan ini antara lain: gangguan tidur, kelelahan, penyakit jantung, tekanan darah tinggi, dan gangguan gastrointestinal. Segala gangguan kesehatan tersebut, ditambah tekanan stress yang besar dapat secara otomatis meningkatkan resiko terjadinya kecelakaan pada para pekerja Shift malam.

\section{C.Cara memilih Sistem Shift Kerja}

Pada dasarnya, terdapat 3 (tiga) aspek penting yang perlu diperhatikan dalam pemilihan sistem shift, yakni:

1. Kesehatan dan Keselamatan Pekerja

2. Performansi Kerja

3. Interaksi Sosial

Selanjutnya dalam menentukan shit kerja yang sesuai, kriteria perlu ditetapkan untuk mendapatkan sistem yang disetujui banyak pihak. Sebagai contoh, seseorang dapat membuat kebutuhan kerja sebagai berikut:

1. Waktu kerja tiap hari tidak boleh lebih dari 8 jam.

2. Jumlah shift kerja malam yang berurutan untuk seorang pekerja, harus ditekan sekecil mungkin.

3. Setiap shift malam harus diikuti dengan waktu libur setidaknya 24 jam

4. Tiap perencanaan shift kerja mesti meliputi akhir pekan, paling tidak 2 hari berurutan.

Dari peninjauan psikologis, fisiologis, performansi dan tingkah laku sosial, rekomendasi berikut patut dijadikan acuan bagi perencanaan shift kerja, yaitu:

1. Aktivitas kerja harus mengikuti pola kebiasaan tubuh.

2. Pelaksanaan kerja di siang hari lebih disukai.

3. Shift sore hari lebih disukai daripada shift malam.

4. Bila pembagian shift diperlukan terdapat dua aturan yang berlawanan yaitu:

a. Pekerja melakukan hanya 1 (satu) shift malam/sore dalam 1 (satu) minggu kerja atau

b. Secara permanen melakukan shift malam.

5. Waktu kerja cukup dilakukan 8 jam selama satu shift, tetapi bagi pekerjaan yang membutuhkan perhatian mental/fisik tinggi, sebaiknya waktu kerjanya dipersingkat. Sebaliknya waktu kerja tiap shift dapat diperpanjang pada pekerjaan yang sifatnya rutin.

6. Jam kerja minggu yang terkompresi sebaiknya dilakukan pada pekerjaan yang rutin, contohnya 10 jam pada 4 hari kerja.

\section{D.Jam Kerja Menurut Undang-undang}

Jam Kerja, waktu istirahat kerja, dan waktu lembur diatur dalam pasal 77 sampai pasal 85 Undang-undang No. 13 tahun 2003 tentang Ketenagakerjaan. Di beberapa perusahaan, jam kerja, waktu istirahat dan lembur dicantumkan dalam Perjanjian Kerja Bersama (PKB). Untuk karyawan yang bekerja 6 hari dalam seminggu, jam kerjanya adalah 7 jam dalam 1 hari dan 40 jam dalam 1 minggu. Sedangkan untuk karyawan dengan 5 hari kerja dalam 1 minggu, kewajiban bekerja mereka 8 jam dalam 1 hari dan 40 jam dalam 1 minggu.

Pasal 77 ayat 1, Undang-undang No.13/2003 mewajibkan setiap pengusaha untuk melaksanakan ketentuan jam kerja. Ketentuan jam kerja ini telah diatur dalam 2 (dua) sistem seperti yang telas disebutkan diatas, yaitu:

1. Tujuh (7) jam kerja dalam 1 hari atau 40 jam kerja dalam 1 minggu untuk 6 hari kerja dalam 1 minggu; atau

2. Delapan (8) jam kerja dalam 1 hari atau 40 jam kerja dalam 1 minggu untuk 5 hari kerja dalam 1 minggu.

Waktu kerja lembur adalah waktu kerja yang melebihi 7 jam sehari untuk 6 hari kerja dan 40 jam dalam seminggu atau 8 jam sehari untuk 8 hari kerja dan 40 jam dalam seminggu atau waktu kerja pada hari istirahat mingguan dan atau pada hari libur resmi yang ditetapkan 
Pemerintah (Pasal 1 ayat 1 Peraturan Menteri No. 102/MEN/VI/2004). Waktu kerja lembur hanya dapat dilakukan paling banyak 3 jam/hari dan 14 jam dalam 1 minggu diluar istirahat mingguan atau hari libur resmi. Perhitungan upah lembur didasarkan upah bulanan dengan cara menghitung upah sejam adalah 1/173 upah sebulan. Berdasarkan ketentuan yang tertuang dalam Kepmenakertrans No. 102/MEN/VI/2004, rumus perhitungan upah lembur dapat dilihat pada tabel berikut:

Tabel Rumus Perhitungan Upah Lembur Pada Hari Kerja

\begin{tabular}{|c|c|c|}
\hline $\begin{array}{l}\text { Jam } \\
\text { Lembur } \\
\end{array}$ & Rumus & Keterangan \\
\hline Jam Pertama & $\begin{array}{l}1.5 \times 1 / 173 \times \text { Upah } \\
\text { Sebulan }\end{array}$ & $\begin{array}{l}\text { Upah sebulan adalah } \\
100 \% \text {, bila upah yang } \\
\text { berlaku diperusahaan } \\
\text { terdiri dari upah pokok dan } \\
\text { tunjangan tetap. }\end{array}$ \\
\hline $\begin{array}{ll}\text { Jam } & \mathrm{Ke}-2 \\
\text { dan } 3 & \end{array}$ & $\begin{array}{l}2 \times 1 / 173 \quad x \quad \text { Upah } \\
\text { Sebulan }\end{array}$ & $\begin{array}{l}\text { Upah sebulan adalah } 75 \% \text {, } \\
\text { jika upah yang berlaku } \\
\text { diperusahaan terdiri dari } \\
\text { upah pokok, tunjangan } \\
\text { tetap dan tunjangan tidak } \\
\text { tetap dengan ketentuan } \\
\text { upah sebulan lebih rendah } \\
\text { dari upah minimum. }\end{array}$ \\
\hline
\end{tabular}

(Sumber: Kementerian Tenaga Kerja RI)

\section{F.Metode Algoritma Tibrewala, Philippe, dan Browne}

Metode ini pertama kali diperkenalkan oleh Tibrewala, Philippe, dan Browne pada tahun 1972. Tujuan dari algoritma ini adalah untuk memenuhi permintaan terhadap pekerja dengan meminimumkan jumlah pekerja yang harus disiapkan. Adapun langkah-langkah dalam menentukan algoritma ini adalah sebagagai berikut:

1. Mulai dari dengan kebutuhan tenaga kerja terbesar, kemudian terbesar kedua, dan seterusnya. Tempatkan kebutuhan hari yang memiliki kebutuhan sama dalam jadwal hingga diperoleh 2 hari berturutan yang unik dan menunjukan jadwal untuk 5 hari kerja 2 hari libur. Bila hal ini tidak dapat dilakukan, maka lakukanlah langkah ke-2.

2. Bila terdapat 2 pasangan hari libur yang berurutan, pilih hari yang memiliki kebutuhan terkecil pada hari yang berdekatan. Bila hal ini tidak dapat dilakukan, maka lakukanlah langkah ke-3.

Pilih pasangan hari yang paling beralasan, missal pilih pasangan hari sabtu dan minggu sebagai hari libur.

\section{METODOLOGI PENELITIAN \\ A.Ruang Lingkup Penelitian}

Adapun ruang lingkup penelitian ini dibatasi berdasarkan tempat dan obyek penelitian, yaitu sebagai berikut:

\section{Jenis Penelitian}

Penelitian yang dilakukan oleh penulis adalah studi kasus dengan obyek tertentu, yaitu mengenai penjadwalan tenaga kerja di PT. Hi-Lex Parts Indonesia, adapun hasilnya akan dibandingkan dengan penjadwalan yang sudah ada untuk mempertimbangkan dalam pengurangan ataupun menghilangkan overtime pada hari sabtu dan minggu.

\section{Obyek Penelitian}

Obyek penelitian yang dilakukan penulis adalah teknik proses penjadwalan tenaga kerja yang terjadi di PT. Hi-Lex Parts Indonesia.

\section{Tempat dan Waktu Penelitian}

Pada penelitian ini, penulis melakukan penelitian yang dilaksanakan adalah di PT. Hi-Lex Parts Indonesia, yang beralamatkan di Jalan Bouraq No. 35 Kelurahan Karang Anyar, Kecamatan Neglasari, Kota Tangerang, Provinsi Banten. Adapun waktu penelitian ini dilaksanakan dimulai dari bulan Mei 2014 sampai dengan bulan Agustus 2014.

\section{B.Metode Pengumpulan Data}

Penentuan metode pengumpulan data dipengaruhi oleh jenis dan sumber data yang diperlukan. Adapun metodologi dalam pengumpulan data yang dilakukan pada penulisan ini adalah:

\section{Studi Pustaka}

Penelitian kepustakaan yaitu suatu penelitian yang dilakukan dengan cara mempelajari dan mengumpulkan bahan-bahan kepustakaan dan literatur yang ada kaitannya dengan penelitian ini.

\section{Teknik Lapangan}

Teknik lapangan adalah teknik pengumpulan data yang dilakukan dengan cara langsung dilokasi penelitian. 


\section{C.Jenis dan Sumber Data}

Adapun jenis data yang digunakan penulis dalam penelitian ini adalah sebagai berikut:

\section{Data Kualitatif}

Data kualitatif adalah data yang berupa huruf, gambar, diagram dan lain sebagainya (bukan angka) yang menjabarkan sesuatu atau kata-kata.

\section{Data Kuantitatif}

Data kuantitaif adalah informasi yang diperoleh dari perusahaan dalam bentuk angka-angka, seperti laporan jumlah material, harga material, dan lain-lain. Sedangkan sumber data yang digunakan dalam penulisan ini adalah sebagai berikut:

\section{a. Data Primer \\ b. Data Sekunder}

\section{D.Flowchart Penelitian}

Adapun diagram flowchart atau alur proses pada penelitian ini ditujukan pada gambar berikut:

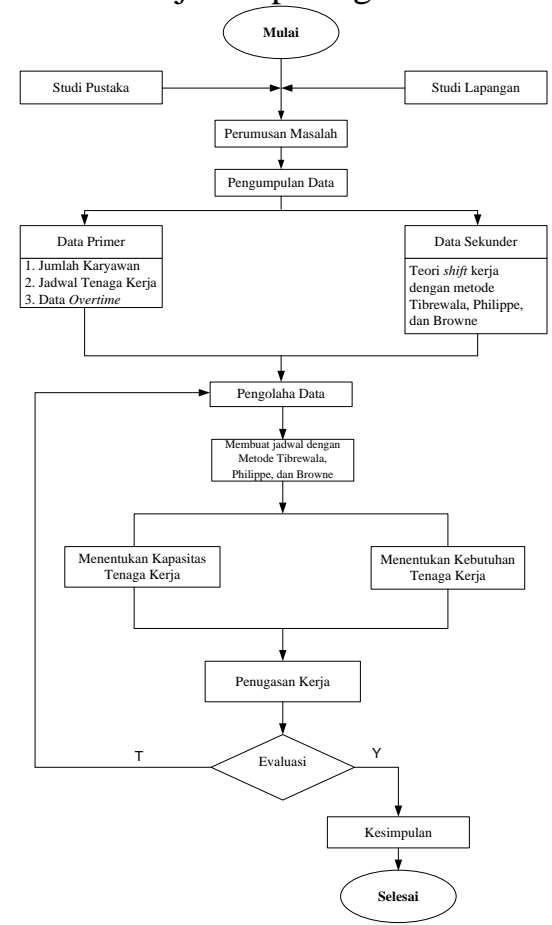

Gambar Flowchart Metodologi Penelitian

\section{Langkah Penelitian}

Berdasarkan perumusan masalah yang disusun, urutan langkah-langkah yang dilakukan dalam melakukaan penelitian ini terdiri dari beberapa tahap, yaitu:
1. Menentukan Tema

2. Mengadakan survei lapangan dan mempelajari serta mengumpulkan bahanbahan yang berkaitan dengan penelitian guna merumuskan masalah.

3. Perumusan Masalah

4. Studi Literatur

5. Pengumpulan Data Pengumpulan data yang dilakukan penulis terdiri dari 2 (dua) tahapan, yaitu:

a. Dokumen Perusahaan

b. Data Analisis Biaya

6. Proses Penjadwalan Tenaga Kerja

7. Evaluasi

8. Kesimpulan

\section{HASIL DAN PEMBAHASAN}

\section{A.Jadwal Tenaga Kerja}

Sistem kerja karyawan yang terjadi di PT. Hi-Lex Parts Indonesia mempunyai batasan jam kerja yang sesuai dengan Undang-undang No. 13/2003, yaitu 40 (empat puluh) jam dalam 1 (satu) minggu dalam 5 (lima) hari kerja dengan sistem non-shift. Pada umumnya jam kerja di PT. Hi-Lex Parts Indonesia dimulai pada hari Senin sampai dengan Kamis mulai dari jam 07.40 09.50, dengan jam istirahat I selama 10 menit, yaitu pada jam 09.50-10.00. Kemudian kerja dilanjutkan jam 10.00-12.00 dengan jam istirahat II untuk melakukan shalat dan makan siang pada jam 12.00-12.40, kerja dilanjutkan kembali pada jam 12.40-15.40 dan istirahat selama 10 menit pada jam 15.40-15.55, kemudian kerja lagi pada jam 15.55-17.00. Sedangkan jam kerja pada hari Jumat sama dengan hari sebelumnya kecuali pada jam kerja dan waktu istirahat ke-2, untuk jam kerja ke-2 mulai dari jam 10.00-11.30 dan waktu istirahatnya mulai dari jam 11.30-12.40. lebih lengkapnya untuk jadwal jam kerja di PT. Hi-Lex Parts Indonesia dapat dilihat pada tabel berikut:

Tabel Jam Kerja PT. Hi-Lex Parts Indonesia

\begin{tabular}{|c|c|c|c|c|c|c|c|}
\hline Hari & Kerja & Istirahat I & Kerja & Istirahat II & Kerja & Istirahat II & Kerja \\
\hline $\begin{array}{l}\text { Senins/d } \\
\text { Kamis }\end{array}$ & | $07.40-1$ & $19.50-10.000$ & $10,00-12,2,0$ & $12,0-12,40$ & 12:40-15.40 & $|15,40-15.55|$ & $1555-17.00$ \\
\hline Jumat & 107.40-99.50 & 09.50-10.00 & 10.00-11.30 & $11,30-12,40$ & 12.40-15:40 & $\mid 15,40-15.55$ & 15.55-17.00 \\
\hline
\end{tabular}

\section{B.Data Proses Assembling Komponen}


Data yang disajikan pada penelitian ini merupaka data siklus yang dikumpulkan adalah data Cycle Time Assy Inspection, data proses assembling komponen dapat dilihat pada tabel berikut:

Tabel Data Proses Assembling Komponen

\begin{tabular}{l|r|r}
\multicolumn{1}{c|}{ Komponen } & $\begin{array}{c}\text { Cycle Time } \\
\text { (Second) }\end{array}$ & $\begin{array}{c}\text { Jml } \\
\text { Pengecekan/Minggu }\end{array}$ \\
\hline \hline AJ30235FO & 6 & 162,000 \\
AL21316FO & 8 & 162,000 \\
AC80152FO & 10 & 162,000 \\
Jumlah & $\mathbf{2 4}$ & $\mathbf{4 8 6 , 0 0 0}$ \\
\hline Nilai Rata-rata & $\mathbf{8}$ & \\
\hline
\end{tabular}

(Sumber: PT. Hi-Lex Parts Indonesia)

\section{C.Data Tenaga Kerja}

PT. Hi-Lex Parts Indonesia mempunyai jumlah tenaga kerja pada Divisi Finishing bagian Assy Inspection adalah sebanyak 21 orang, diantaranya adalah pada assy komponen AJ30235FO sebanyak 6 orang, komponen AL21316FO sebanyak 7 orang, dan pada komponen AC80152FO sebanyak 8 orang. Lebih lengkapnya dapat dilihat pada tabel berikut:

Tabel Data Tenaga Kerja Proses Assembling Komponen

\begin{tabular}{|l|c|}
\hline \multicolumn{1}{|c|}{ Komponen } & Tenaga Kerja \\
\hline AJ30235FO & 6 \\
AL21316FO & 7 \\
AC80152FO & 8 \\
\hline Jumlah & $\mathbf{2 1}$ \\
\hline
\end{tabular}

(Sumber: PT. Hi-Lex Parts Indonesia)

\section{Sistem Shift Kerja}

Sistem shift tenaga kerja Divisi Finishing Bagian Assy Inspection PT. Hi-Lex Parts Indonesia menggunakan sistem shift tetap (permanent) atau non-shift. Jadwa shift kerja dan kebutuhan karyawan yang terjadi dapat dilihat pada tabel berikut:

Tabel Sistem Shift Kerja

\begin{tabular}{cc|c|c|c|c|c|c|}
\hline Hari Senin & Selasa & Rabu Kamis Jumat & \multicolumn{2}{|c|}{ Overtime } \\
\cline { 5 - 8 } & & & & & Sabtu & Mingou \\
\hline \hline Kebutuhan & 21 & 21 & 21 & 21 & 21 & 18 & 12 \\
\hline
\end{tabular}

(Sumber: PT. Hi-Lex Parts Indonesia)

Jadi, total hari kerja dalam seminggu adalah 5 hari dan hari sabtu dan minggu termasuk overtime.

\section{Sistem Upah dan Penggajian}

Adapun rincian dari upah yang terjadi di PT. Hi-Lex Parts Indonesia adalah sebagai berikut: Gaji Pokok =2.810.946,-

Tunjangan Transport $=$ per hari Rp. $12.000 \mathrm{x}$ 21 hari dalam sebulan

$$
\begin{aligned}
& \qquad=\text { Rp. } 252.000,- \\
& \text { Uang Makan } \\
& \begin{array}{r}
\text { hari dalam sebulan hari Rp. } 9.500 \times 21 \\
\text { Premi Hadir } \quad \text { Rp. } 199.500,-
\end{array} \\
& =75.000,- \text { per bulan }
\end{aligned}
$$

Jadi, jumlah gaji yang diterima oleh karyawan adalah sebesar Rp. 3.337.446,- jika karyawan mengikuti lembur (overtime) kerja, maka perhitungan upah lemburnya sebagai berikut:

Overtime $\quad=2 \times 1 / 173 \times$ Upah

Sebulan

$$
=2 \times 1 / 173 \times 2.810 .946,-
$$

Maka, biaya lembur seluruh karyawan pada hari sabtu dan minggu selama 1 (satu) bulan) adalah Rp. 259.971,88,- x 30 (kebutuhan karyawan) x 4 = Rp. 31.196.626,-

\section{E. Pembuatan Shift Kerja Dengan Metode} Algoritma Tibrewala, Philippe, dan Browne Penjadwalan tenaga kerja dengan menggunakan Algoritma Tribewala, Philippe, dan Browne terdiri dari 3 (tiga) langkah yang diulangi secara iterative hingga nilai kebutuhan tenaga kerja bernilai 0 (nol) atau negatif. Perubahan aturan pemilihan hari libur dilakukan karena adanya beberapa pertimbangan dan constraint. Berikut ini langkah dalam penjadwalan Algoritma Tribewala, Philippe, dan Browne:

1. Menentukan Kebutuhan Tenaga Kerja

Kebutuhan tenaga kerja per hari dalam 1 (satu) minggu, bagi kebutuhan tenaga kerja per hari kerja dalam kebutuhan tiap penugasan adalah sebagai berikut:

Kapasitas per tenaga kerja $=3.600$

Kebutuhan tenaga kerja = $\underline{\text { Jumlah pengecekan per minggu }}$

Kapasitas

per tenaga kerja

$$
=\frac{486.000 \mathrm{Pcs}}{3.600 \mathrm{Pcs}}=
$$

135 tenaga kerja 
Kebutuhan tenaga kerja dalam format tabular dapat dilihat pada tabel berikut:

Tabel Format Tabular Penjadwalan Tenaga Kerja

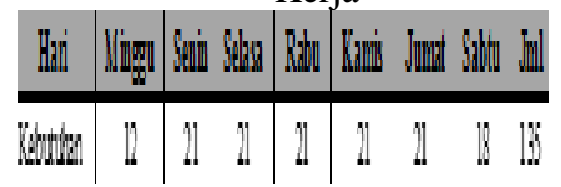

(Sumber: Pengolahan Data)

2. Menentukan Kebutuhan Penugasan Kerja Kebutuhan penugasan kerja dalam 1 (satu) minggu, caranya adalah sebagai berikut: Kebutuhan penugasan kerja $=\quad \underline{\text { Total }}$ kebutuhan tenaga kerja per minggu 27 penugasan

Maka hasil kebutuhan penugasan kerja adalah sebanyak 27 penugasan kerja per minggu.

3. Pengolahan Data

Setelah diperoleh data-data

yang diperlukan, selanjutnya data tersebut digunakan untuk pengolahan data sebagai berikut:
a. Sabtu-Minggu $2,3,4,8,12,16,20$, dan 24
b. Minggu-Senin $9,13,19,21$, dan 25
c. Selasa-Rabu= Penugasan 6, 10, 14, 18, 22, dan 26
d. Kamis-Jumat = Penugasan 7, $11,15,19,23$, dan 27

Dilihat dari pengolahan data diatas, penjadwalan penugasan kerja menggunakan Metode Algoritma Tribewala, Philippe, dan Browne membutuhkan tenaga kerja sebanyak 27 orang dari penjadwalan dengan sistem Penugasan kerja yang terjadi sebelumnya, berarti diperlukan penambahan tenaga kerja baru sebanyak 6 orang. Adapun hasil kebutuhan tenaga kerja dapat dilihat pada tabel berikut:

Tabel Hasil Kebutuhan dan Penjadwalan Penugasan Kerja

\begin{tabular}{l|c|c|c|c|c|c|c|}
\hline & Minggu & Senin & Selasa & Rabu & Kamis & Jumat & Sabtu \\
\hline \hline Staff & 12 & 21 & 21 & 21 & 21 & 21 & 18 \\
\hline Demand & 12 & 21 & 21 & 21 & 21 & 21 & 18 \\
\hline Over staff & 0 & 0 & 0 & 0 & 0 & 0 & 0 \\
\hline
\end{tabular}

\section{E.Pembahasan}

(Sumber: Pengolahan Data)

Penjadwalan yang sekarang terjadi di bagian Assy Inspection PT. Hi-Lex Parts Indonesia dilakukan sistem 5 (lima) hari kerja (nonPenugasan) dengan jam kerja per hari adalah 8 (delapan) jam kerja atau 40 jam kerja/minggu, akan tetapi hari Sabtu dan Minggu libur yang digunakan PT. Hi-Lex Parts Indonesia sebagai lembur (overtime).

Jumlah tenaga kerja semula adalah 21 orang dengan upah atau gaji sebesar Rp. 3.337.446,yang terdiri dari gaji pokok, tunjangan transportasi, uang makan, dan premi kehadiran. Maka jumlah gaji yang dikeluarkan PT. Hi-Lex Parts Indonesia dalam 1 (satu) tahun dengan jumlah tenaga kerja di bagian Assy Inspection 21 orang adalah sebesar Rp. 841.036.392,-. Untuk perhitungan kerja lembur (overtime) adalah $2 \mathrm{x}$ 1/173 x Upah Sebulan (Kepmenakertrans No. 102/MEN/VI/2004) sebesar Rp. 32.496,- per jam dikali 8 jam/hari adalah sebesar Rp. 259.971,88,per/hari. Maka biaya lembur pada hari sabtu dan minggu selama 1 (satu) bulan) adalah Rp. 259.971,88,- x 30 (kebutuhan karyawan) x 4 adalah sebesar Rp. 31.196.626,-, jika dalam 1 (satu) tahun biaya yang dikeluarkan sebesar Rp. 31.196.626,- dikali 12 bulan adalah sebesar Rp. 374.359.512,-. Maka PT. Hi-Lex Parts Indonesia mengeluarkan total biaya upah atau gaji dalam 1 (satu) tahun untuk bagian Assy Inspection adalah sebesar Rp. 1.215.395.904,- (Satu milyar dua ratus lima belas juta tiga ratus Sembilan puluh lima ribu Sembilan ratus empat rupiah).

Dengan penjadwalan Penugasan kerja menggunakan metode Algoritma Tibrewala, Philippe, dan Browne, PT. Hi-Lex Parts Indonesia dibagian Assy Inspection membutuhkan tenaga kerja sebanyak 27 orang menggunakan sistem 5 (lima) hari kerja dengan jam kerja 40 jam/minggu, 2 (dua) hari libur tanpa ada overtime di hari Sabtu dan Minggu. Maka PT. Hi-Lex Parts Indonesia akan mengeluarkan upah atau gaji dalam 1 (satu) tahun Rp. 3,337.446,dikali 27 orang selama 12 bulan adalah sebesar Rp. 1.081.332.504,- (Satu milyar delapan puluh satu juta tiga ratus tiga puluh dua ribu lima ratus rupiah).

Maka selisih upah atau gaji sistem PT. Hi-Lex Parts Indonesia dengan sistem Penugasan kerja menggunakan Metode Algoritma Tibrewala, 
Philippe, dan Browne adalah sebesar Rp. 134.063.400,- per tahun. Selisih upah yang terjadi dapat dilihat pada gambar berikut:

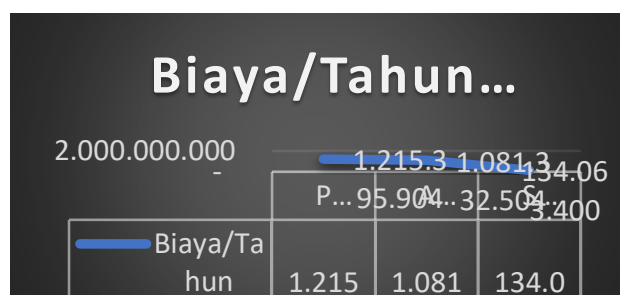

Gambar Selisih Upah Biaya PT. Hi-Lex Parts Indonesia

(Sumber: Pengolahan Data)

Dengan Metode Algoritma Tibrewala, Philippe, dan Browne tersebut, tenaga kerja akan mendapatkan performance yang optimal dalam bekerja untuk meningkatkan produktifitas dan PT. Hi-Lex Parts Indonesia akan menghemat biaya sebesar $11 \%$ (sebelas persen) dari pengeluaran sebelum menggunakan metode ini.

\section{KESIMPULAN}

Berdasarkan hasil penelitian dan pembahasan yang dilakukan oleh penulis di PT. Hi-Lex Parts Indonesia di bagian Assy Inspection, maka dapat diambil kesimpulan sebagai berikut:

1. Sistem shift kerja yang terjadi di bagian Assy Inspection PT. Hi-Lex Parts Indonesia adalah sebagai berikut:

a. Jumlah tenaga kerja adalah 21 orang, sistem 5 (lima) hari kerja (non-shift) dan 8 (delapan) jam kerja per hari, sedangkan hari Sabtu dan Minggu digunakan lembur (overtime).

b. Jika menggunakan Metode Algoritma Tibrewala, Philippe, dan Brown terjadi penambahan tenaga kerja menjadi 27 orang, yaitu 5 (lima) hari kerja, dan 8 (delapan) jam kerja tanpa adanya overtime (lembur). c. Total pengeluaran biaya upah per tahun adalah sebesar Rp. 1.215.395.904,- jika menggunakan Metode Algoritma Tibrewala, Philippe, dan Brown jumlah biaya upah per tahun sebesar Rp. 1.081.332.504,-.

2. Langkah-langkah dalam membuat sistem shift kerja menggunakan Metode Algoritma Tibrewala, Philippe, dan Brown adalah sebagai berikut:

a. Menyusun kebutuhan tenaga.

b. Menentukan kebutuhan shift kerja.

c. Memasukan kebutuhan tenaga kerja ke dalam kebutuhan shift kerja dengan format tabel hingga di dapat kebutuhan tenaga kerja dengan nilai 0 (nol).

\section{DAFTAR PUSTAKA}

Husen, Abrar, (2009), Manajemen Proyek,Perencanaan,Penjadwalan dan Pengendalian Proyek, Yogyakarta : Andi.

Keputusan Bersama Menteri Tenaga Kerja dan Kepala Kepolisian RI Nomor Kep.275/Men/1989 dan Nomor Pol.Kep /04/V/1989 tentang Pengaturan Jam Kerja, Shift dan Jam Istirahat serta Pembinaan Tenaga Satuan Pengamanan (SATPAM).

Luce, B. J, (1983), "A Shift Scheduling Algorithm", Reported in E. S Buffa, Modern Production/Operation Management, 7 edition. New York; John Wiley

Monroe, G, (1970), "Scheduling Manpower for Service Operations," Industrial Engineering,aug.

Nasution, Arman Hakim, (2005), Manajemen Industri. Surabaya: Andi.

Nurmianto, Eko, (2004), Ergonomi Konsep dan Dasar Aplikasinya. Surabaya: Guna Widya

Rahman, Arif, (2007), Penjadwalan Shift Tenaga Kerja pada Sistem NonStationary Poisson Process, Diagonal 8. No 1,63-73. 